\title{
Upaya Meningkatkan Kemampuan Guru dalam Menggunakan Model Pembelajaran Melalui Supervisi Klinis di SD Negeri 168/X Pandan Sejahtera Tanjung Jabung Timur
}

\author{
Sukanto, S.Pd. \\ SD Negeri 168/X Pandan Sejahtera \\ Jl. Singosari, Pandan Sejahtera, Kec. Geragai, Kab. Tanjung Jabung Timur Prov. Jambi \\ Sukanto463@gmail.com
}

\begin{abstract}
This study aims to disclose information and discuss the Efforts to Improve Teacher Ability in Using Learning Models through Clinical Supervision at SD Negeri 168/X Pandan Sejahtera Tanjung Jabung Timur. This research is included in the type of school action research (PTS). This research was carried out in this research was carried out at SD Negeri 168/X Pandan Sejahtera. The time of this research was carried out in the odd semester of the 2021 - 2022 school year, which began in July 2021. The subjects in this study were 8 teachers of SD Negeri 168/X Pandan Sejahtera. The research procedure consisted of two cycles with four stages of research starting from planning, implementing, observing and reflecting. Data collection in this study was carried out using instruments, observations and documents. The data were analyzed using the percentage formula. The results of this study indicate that clinical supervision can improve the ability of teachers in using the learning model of SD Negeri 168/X Pandan Sejahtera which is marked by an increase from pre-cycle, cycle I, cycle II.
\end{abstract}

Keywords: Teacher's Ability to Use Learning Models, Clinical Supervision

\begin{abstract}
Abstrak
Penelitian ini bertujuan untuk mengungkapkan informasi dan membahas tentang Upaya Meningkatkan Kemampuan Guru dalam Menggunakan Model Pembelajaran melalui Supervisi Klinis di SD Negeri 168/X Pandan Sejahtera Tanjung Jabung Timur. Penelitian ini termasuk dalam jenis penelitian tindakan sekolah (PTS). Penelitian ini dilaksanakan di Penelitian ini dilaksanakan di SD Negeri 168/X Pandan Sejahtera. Waktu penelitian ini dilaksanakan pada semester ganjil tahun pelajaran 2021 - 2022, yang dimulai pada bulan Juli 2021. Subjek dalam penelitian ini adalah guru SD Negeri 168/X Pandan Sejahtera berjumlah 8 orang. Prosedur penelitian terdiri dari dua siklus dengan empat tahap peneletian mulai dari perencanaan, pelaksanaan, observasi dan refleksi. Pengumpulan data dalam penelitian ini dilakukan dengan menggunakan instrumen, observasi dan dokumen. Data dianalisis dengan menggunakan rumus persentase. Hasil penelitian ini menunjukkan bahwa Melalui Supervisi Klinis dapat meningkatkan Kemampuan Guru dalam Menggunakan Model Pembelajaran SD Negeri 168/X Pandan Sejahtera yang ditandai oleh meningkatnya dari pra siklus, siklus I, siklus II.
\end{abstract}

Kata Kunci : Kemampuan Guru Menggunakan Model Pembelajaran, Supervisi Klinis

Corresponding author: Sukanto

Copyright (c) 2021 Sukanto

Email Address: sukanto463@gmail.com (Jl. Singosari, Pandan Sejahtera, Kec. Geragai, Jambi)

Received 01 December, Accepted 13 December 2021, Published 30 December 2021

\section{PENDAHULUAN}

Pendidikan merupakan investasi dalam pengembangan sumber daya manusia dan dipandang sebagai kebutuhan dasar bagi masyarakat yang ingin maju. Komponen-komponen sistem pendidikan yang mencakup sumber daya manusia dapat digolongkan menjadi dua yaitu : tenaga kependidikan guru dan non guru. Menurut Undang-undang Nomor 20 tahun 2003 tentang Sistem Pendidikan Nasional menyatakan, "komponen-komponen sistem pendidikan yang bersifat sumber daya manusia dapat digolongkan menjadi tenaga pendidik dan pengelola satuan pendidikan (Guru, Kepala 
Sekolah, penilik, pengawas, peneliti, dan pengembang pendidikan)." Tenaga guru dan kepala sekolahlah yang mendapat perhatian lebih banyak diantara komponen-komponen sistem pendidikan. Besarnya perhatian terhadap guru dan Kepala sekolah dapat dilihat dari banyaknya kebijakan khusus seperti tunjangan fungsional guru dan sertifikasi guru.

Menurut Undang-Undang Republik Indonesia Nomor 14 Tahun 2005 Tentang Guru dan Dosen menyatakan bahwa kompetensi adalah seperangkat pengetahuan, keterampilan, dan perilaku yang harus dimiliki, dihayati, dan dikuasai oleh guru atau dosen dalam melaksanakan tugas keprofesionalan. Menurut Finch \& Crunkilton, (1992: 220) Menyatakan "Competencies are those taks, skills, attitudes, values, and appreciation that are deemed critical to successful employment". Pernyataan ini mengandung makna bahwa kompetensi meliputi tugas, keterampilan, sikap, nilai, apresiasi diberikan dalam rangka keberhasilan hidup/penghasilan hidup. Hal tersebut dapat diartikan bahwa kompetensi merupakan perpaduan antara pengetahuan, kemampuan, dan penerapan dalam melaksanakan tugas di lapangan kerja.

Pendidikan merupakan pintu gerbang untuk membuka dunia, maka pendidikan yang bermutu, kuat dan kokoh diyakini masih menjadi harapan bagi semua orang. Untuk mencapai tujuan seperti tersebut di atas, salah satu komponen sekolah yang memegang peranan penting adalah kepala sekolah. Hal Ini diharapkan dapat menjadi sumber daya yang seyogianya memiliki keunggulan dan kompetensi untuk membina, membimbing, dan melatih guru-guru. Selain itu kepala sekolah dituntut juga agar senantiasa memberikan bantuan layanan kepada personil sekolah.

Mills (dalam Suprijono, 2012: 45) berpendapat bahwa "Model adalah bentuk representasi akurat sebagai proses aktual yang memungkinkan seseorang atau sekelompok orang mencoba bertindak berdasarkan model itu". Model merupakan interpretasi terhadap hasil observasi dan pengukuran yang diperoleh dari beberapa sistem. Sedangkan Joyce dan Weil (dalam Rusman, 2013:133) berpendapat bahwa model pembelajaran adalah suatu rencana atau pola yang dapat digunakan untuk membentuk kurikulum (rencana pembelajaran jangka panjang) merancang bahanbahan pembelajaran, dan membimbing pembelajaran di kelas atau yang lain.

Berdasarkan observasi awal yang penulis lakukan di SD Negeri 168/X Pandan Sejahtera Tanjung Jabung Timur penulis sebagai kepala sekolah melihat masih kurang kemampuan guru dalam menggunakan model pembelajaran yang tepat. Hal ini dikarenakan guru hanya terbiasa memberikan metode konvensional atau ceramah sehingga kurang memahami model pembelajaran lain yang lebih kreatif dan inovatif. Maka oleh sebab itu peneliti ingin memberikan perubahan tentang kebiasaan tersebut melalui supervisi klinis. Berdasarkan latar belakang masalah diatas, Penelitian ini bertujuan untuk mendapatkan data/informasi dan membahas tentang Upaya Meningkatkan Kemampuan Guru Dalam Menggunakan Model Pembelajaran Melalui Supervisi Klinis di SD Negeri 168/X Pandan Sejahtera Tanjung Jabung Timur.

Kemampuan berasal dari kata mampu yang berarti kuasa (bisa, sanggup) melakukan sesuatu, sedangkan kemampuan berarti kesanggupan, kecakapan, kekuatan (Tim Penyusun Kamus Besar 
Bahasa Indonesia, 1989: 552-553). Kemampuan (ability) berarti kapasitas seorang individu untuk melakukan beragam tugas dalam suatu pekerjaan. (Stephen P. Robbins \& Timonthy A. Judge, 2009: $57)$.

Lebih lanjut, Stephen P. Robbins \& Timonthy A. Judge (2009: 57-61) menyatakan bahwa kemampuan keseluruhan seorang individu pada dasarnya terdiri atas dua kelompok faktor, yaitu : a) Kemampuan Intelektual (Intelectual Ability),merupakan kemampuan yang dibutuhkan untuk melakukan berbagai aktifitas mental (berfikir, menalar dan memecahkan masalah). b) Kemampuan Fisik (Physical Ability), merupakan kemampuan melakukan tugas-tugasyang menuntutstamina, ketrampilan,kekuatan, dan karakteristik serupa.

Dari pengertian-pengertian tersebut dapat disimpulkan bahwa kemampuan adalah kesanggupan atau kecakapan seorang individu dalam menguasai suatu keahlian dan digunakan untuk mengerjakan beragam tugas dalam suatu pekerjaan. Menurut Kamus Besar Bahasa Indonesia (2005: 377), yang dimaksud dengan guru adalah orang yang pekerjaannya (mata pencahariannya, profesinya) mengajar. Pengertian guru menurut KBBI di atas, masih sangat umum dan belum bisa menggambarkan sosok guru yang sebenarnya, sehingga untuk memperjelas gambaran tentang seorang guru diperlukan definisi-definisi lain.Suparlan dalam bukunya yang berjudul —Menjadi Guru Efektifl, mengungkapkan hal yang berbeda tentang pengertian guru. Menurut Suparlan (2008: 12), guru dapat diartikan sebagai orang yang tugasnya terkait dengan upaya mencerdaskan kehidupan bangsa dalam semua aspeknya, baik spiritual dan emosional, intelektual, fisikal, maupun aspek lainnya. Namun, Suparlan (2008: 13) juga menambahkan bahwa secara legal formal, guru adalah seseorang yang memperoleh surat keputusan (SK), baik dari pemerintah maupun pihakswasta untuk mengajar.

Selain pengertian guru menurut Suparlan, Imran juga menambahkan rincian pengertian guru dalam desertasinya. Menurut Imran (2010: 23), guru adalah jabatan atau profesi yang memerlukan keahlian khusus dalam tugas utamanya seperti mendidik, mengajar, membimbing, mengarahkan, melatih, menilai, dan mengevaluasi siswa pada pendidikan anak usia dini jalur pendidikan formal, pendidikan dasar, dan menengah.Pengertian-pengertian mengenai guru di atas sangat mungkin untuk dapat dirangkum. Jadi, guru adalah seseorang yang telah memperoleh surat keputusan (SK) baik dari pihak swasta atau pemerintah untuk menggeluti profesi yang memerlukan keahlian khusus dalam tugas utamanya untuk mengajar dan mendidik siswa pada pendidikan anak usia dini jalur pendidikan formal, pendidikan dasar, dan menengah, yang tujuan utamanya untuk mencerdaskan bangsa dalam semua aspek.

Mills (dalam Suprijono, 2012: 45) berpendapat bahwa "Model adalah bentuk representasi akurat sebagai proses aktual yang memungkinkan seseorang atau sekelompok orang mencoba bertindak berdasarkan model itu". Model merupakan interpretasi terhadap hasil observasi dan pengukuran yang diperoleh dari beberapa sistem. Sedangkan Joyce dan Weil (dalam Rusman, 2013:133) berpendapat bahwa model pembelajaran adalah suatu rencana atau pola yang dapat 
digunakan untuk membentuk kurikulum (rencana pembelajaran jangka panjang) merancang bahanbahan pembelajaran, dan membimbing pembelajaran di kelas atau yang lain.

Suprijono (2012:45-46) model pembelajaran merupakan landasan praktik pembelajaran hasil penurunan teori psikologi pendidikan dan teori belajar yang dirancang berdasarkan analisis terhadap implementasi kueikulum dan implikasinya pada tingkat operasional di kelas. Model pembelajaran dapat di artikan pula sebagai pola yang digunakan untuk penyusunan kurikulum, mengatur materi, dan memberi petunjuk kepada guru di kelas. Rusman (2013:133) mengatakan model pembelajaran dapat dijadikan pola pilihan, artinya para guru boleh memilih model pembelajaran yang sesuai dan efisien untuk mencapai tujuan pendidikannya

Jadi model pembelajaran adalah cara guru dalam penyampain materi, guru hanya sebagai fasilitator dan siswa lah yang aktif dalam kegiatan pembelajaran. Sehingga dalam memilih model pembelajaran yang tepat haruslah memperhatikan kondisi siswa, sifat materi bahan ajar, fasilitasmedia yang tersedia, dan kondisi guru itu sendiri.

Supervisi memiliki pemahaman yang luas (Purwanto, 2004: 76). Menurut Purwanto menjelaskan bahwa supervisi adalah segala bantuan dari para pemimpin sekolah, yang tertuju pada perkembangan kepemimpinan guru-guru dan personel sekolah lainnya di dalam mencapai tujuantujuan pendidikan. Ia berupa dorongan, bimbingan, dan kesempatan bagi pertumbuhan keahlian dan kecakapan guru-guru, serta bimbingan dalam usaha pelaksanaan pembaharuan-pembaharuan dalam pendidikan dan pengajaran, pemilihan alat-alat pelajaran dan metode pembelajaran yang lebih baik, cara-cara penilaian yang sistematis terhadap fase seluruh proses pengajaran dan sebagainya (2004:76). Pemahaman umum bahwa peranan utama dari supervisi adalah ditujukan kepada perbaikan pengajaran. Franseth Jane dalam Piet A. Sahertian, berkeyakinan bahwa supervisi akan dapat memberi bantuan terhadap program pendidikan melalui bermacam-macam cara sehingga kwalitas kehidupan akan diperbaiki olehnya. Ayer, Frend E, menganggap fungsi supervisi untuk memelihara program pengajaran yang ada dengan sebaik-baiknya sehingga ada perbaikan.

Dari beberapa pengertian tersebut dapat disimpulkan bahwa supervisi klinis adalah suatu proses bimbingan yang bertujuan untuk membantu pengembangan professional guru, khususnya dalam penampilan mengajar, berdasarkan observasi dan analisis data secara objektif sebagai pegangan untuk perubahan tingkah laku mengajar tersebut.

\section{METODE}

Penelitian ini termasuk dalam jenis penelitian tindakan sekolah (PTS). Penelitian ini dilaksanakan di Penelitian ini dilaksanakan di SD Negeri 168/X Pandan Sejahtera. Waktu penelitian ini dilaksanakan pada semester ganjil tahun pelajaran 2021 - 2022, yang dimulai pada bulan Juli 2021. Subjek dalam penelitian ini adalah guru SD Negeri 168/X Pandan Sejahtera berjumlah 8 orang. Prosedur penelitian terdiri dari dua siklus dengan empat tahap peneletian mulai dari perencanaan, pelaksanaan, observasi dan refleksi. Pengumpulan data dalam penelitian ini dilakukan dengan 
menggunakan instrumen, observasi dan dokumen. Data dianalisis dengan menggunakan rumus persentase.

\section{HASIL DAN DISKUSI}

\section{Paparan Pra Siklus}

Pra siklus merupakan kondisi awal sebelum peneliti melakukan kegiatan, dengan menggunakan pola bimbingan biasa. Selanjutnya, berdasarkan hasil data Pra Siklus yang diperoleh, peneliti bersama kepala sekolah melakukan evaluasi mengenai bimbingan yang dianggap tepat, sebagai bentuk tindakan perbaikan dari kemampuan guru dalam menggunakan model pembelajaran.

Hasil proses bimbingan terlihat monoton dan berpusat pada pembimbing, tingkat partisipasi guru dalam bimbingan kurang, banyak guru yang belum mampu menggunakan model pembelajaran yang baik. Dampaknya berpengaruh terhadap kemampuan guru dalam menggunakan model pembelajaran pada saat mengajar dikelas, ini dibuktikan dari hasil observasi yang diamati sebelum supervisi klinis dilakukan. Untuk lebih jelasnya dapat dilihat rekap hasil observasi guru dalam menggunakan model pembelajaran dibawah ini:

Tabel 1. Rekapitulasi Hasil Penelitian Pra Siklus

\begin{tabular}{|c|c|c|c|}
\hline Rentang Nilai & Jumlah & Persentase (100\%) & Predikat \\
\hline$\geq 90 \%$ & 0 & 0 & Amat Baik \\
\hline $81-90 \%$ & 0 & 0 & Baik \\
\hline $71-80 \%$ & 0 & 0 & Cukup \\
\hline$\leq 70 \%$ & 8 & 100 & Kurang \\
\hline Jumlah & 8 & 100 & \\
\hline
\end{tabular}

Berdasarkan hasil pengamatan yang dilakukan sebelum menerapkan supervisi klinis, kemampuan guru dalam menggunakan model pembelajaran di SD Negeri 168/X Pandan Sejahtera Kabupaten Tanjung Jabung Timur masih dikatakan rendah. Hal ini dapat dilihat berdasarkan tabel diatas, dari 8 jumlah guru yang ada semuanya masih dikatakan pada kategori gurang dalam menggunakan model pembelajaran. Oleh sebab itu penulis bersama dengan kepala sekolah mengadakan sebuah tindakan atau perubahan dalam merubah kemampuan guru tersebut ke arah yang lebih baik. Setelah dilakukan diskusi, maka supervisi klinis cocok dilakukan untuk memperbaiki masalah tersebut. Maka supervisi klinis ini akan dijadikan sebagai bentuk perubahan mulai dari siklus I sampai siklus II. Untuk lebih jelasnya mengenai hasil penelitian dari pra siklus ini dapat dilihat pada diagram dibawah ini: 


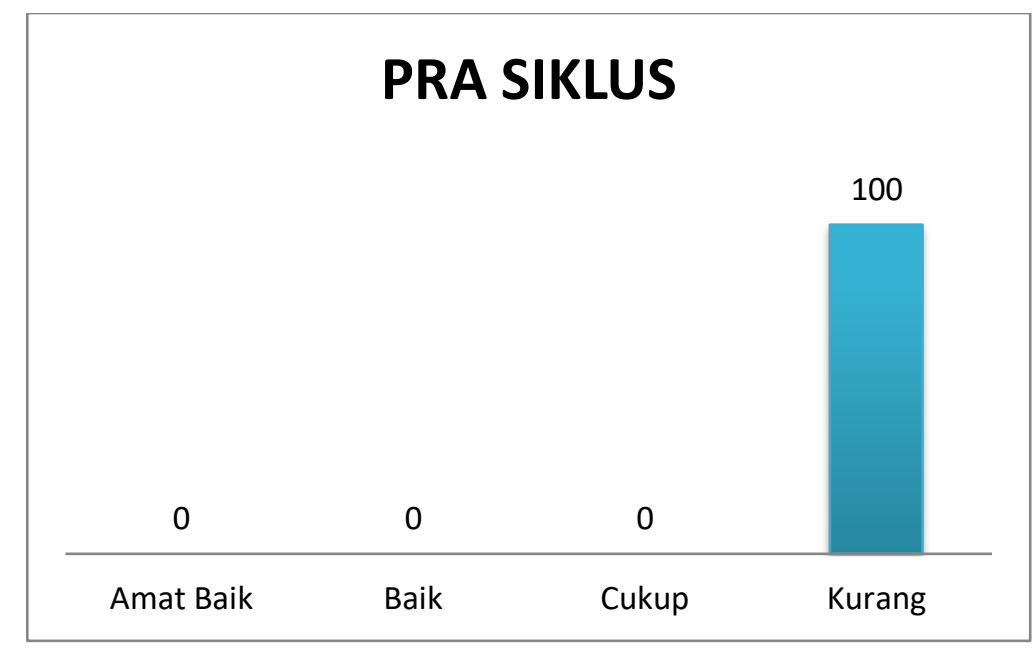

Gambar 1. Hasil Pengamatan Kemampuan Guru Pra Siklus

\section{Siklus I}

\section{Perencanaan}

Dalam perencanaan pada siklus I ini, persiapan yang dilakukan sebelum pelaksanaan tindakan adalah sebagai berikut:

a. Mengumpulkan guru melalui undangan kepala sekolah

b. Menyusun instrumen

c. Menyusun jadwal supervisi klinis mulai dari hari, tanggal, jam serta tempat pertemuan

d. Manyiapkan materi supervisi klinis

e. Menyuruh guru membawa bahan-bahan yang dibutuhkan saat melakukan supervisi klinis

f. Menyiapkan konsumsi untuk supervisi klinis

g. Menyuruh guru membawa laptop dan lainnya

\section{Pelaksanaan}

Pelaksanaan kegiatan pada siklus I ini adalah pada hari sabtu, tanggal 24 Juli 2021 jam 14:0017:00 dengan materi mengenai model pembelajaran yang tepat dalam proses belajar mengajar. Kegiatan ini dilaksamakan di SD Negeri 168/X Pandan Sejahtera Kabupaten Tanjung Jabung Timur dengan jumlah guru sebanyak 8 orang. Adapun kegiatan dalam pelaksanaan ini adalah :

a. Peneliti/pengawas menyampaikan konsep serta pelaksaan penelitian.

b. Memulai melakukan supervisi klinis dengan guru-guru yang sudah dikumpulkan.

c. Meminta guru mengutarakan masalah yang dihadapi dalam melaksanakan penilaian perkembanagan anak.

d. Membimbing guru dalam mengatasi masalah yang dihadapi.

e. Melakukan percobaan serta meminta evaluasi guru terhadap perkembangan yang dinilai.

f. Melakukan tanya jawab mengenai masalah yang telah disupervisikan. 


\section{Observasi}

Pengamatan (observasi) dilaksanakan bersamaan dengan pelaksaaan supervisi dilakukan. Pada akhir proses pelaksanaan kegiatan dilihat kemampuan guru dalam penggunaaan model pembelajaran. Adapun data hasil penelitian pada siklus I adalah sebagai berikut:

Tabel 2. Rekapitulasi Hasil Penelitian Siklus I

\begin{tabular}{|c|c|c|c|}
\hline Rentang Nilai & Jumlah & Persentase (100\%) & Predikat \\
\hline$\geq 90 \%$ & 1 & 12 & Amat Baik \\
\hline $81-90 \%$ & 0 & 0 & Baik \\
\hline $71-80 \%$ & 7 & 88 & Cukup \\
\hline$\leq 70 \%$ & 0 & 0 & Kurang \\
\hline Jumlah & 8 & 100 & \\
\hline
\end{tabular}

Berdasarkan hasil pengamatan yang dilakukan dengan menerapkan supervisi klinis pada siklus I kemampuan guru dalam menggunakan model pembelajaran di SD Negeri 168/X Pandan Sejahtera Kabupaten Tanjung Jabung Timur lengayang rata-rata kemampuan guru masih cukup. Hal ini dapat dilihat berdasarkan tabel diatas, dari 8 jumlah guru yang ada 1 orang guru (12\%) sudah dikategorikan amat baik, 7 orang (88\%) dengan kategori cukup. Oleh sebab itu dari hasil tersebut sudah terjadi peningkatan dari sebelumnya. Untuk lebih jelasnya dapat dilihat pada diagram dibawah ini:

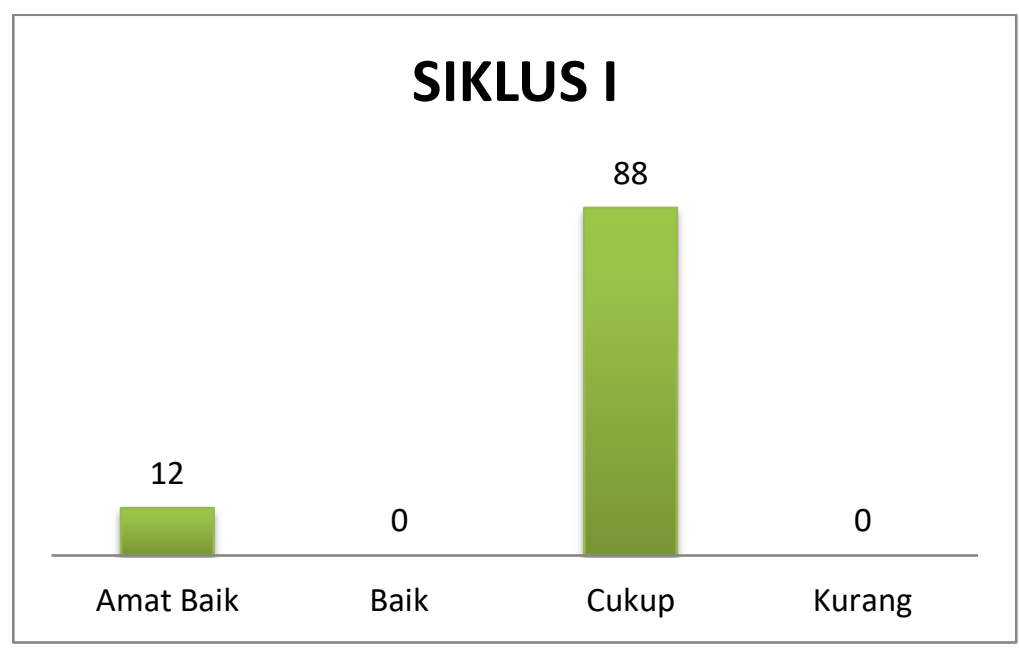

Gambar 2. Hasil Pengamatan Kemampuan Guru Siklus I

\section{Refleksi}

Berdasarkan hasil pengamatan yang dilakukan, maka peneliti bersama dengan kepala sekolah melakukan diskusi yang dilaksanakan diruang majelis guru mengenai proses supervisi yang dilakukan pada siklus I, kepala sekolah yang dijadikan sebagai observer disini memberikan tanggapan atau temuan selama proses pelaksaan supervisi. Adapun temuan yang diamati adalah :

a. Guru belum sepenuhnya mengerti dengan menerapkan model pembelajaran yang cocok.

b. Guru terlihat bingung dan belum paham dengan penjelasan yang disampaikan 
c. Guru masih canggung dengan supervisi klinis

d. Kemampuan guru belum maksimal dalam penggunaan model model pembelajaran.

Berdasarkan masalah atau temuan penelitian dari siklus I ini maka dilakukan tindakan untuk perubahan pada siklus II sehingga masalah pada siklus ini tidak ditemukan lagi pada siklus berikutnya. Maka adapun yang akan dilakukan pada perbaikan untuk siklus berikutnya adalah:

a. Menjelaskan kembali kepada guru mengenai bentuk, contoh serta model pembelajaran yang baik dan tepat dalam sebuah proses pelaksanaan pembelajaran.

b. Menjelaskan kegunaan supervisi klinis bagi guru

c. Memaksimalkan lagi kemampuan guru dalam menggunakan model pembelajaran

d. Menyiapkan hadiah sebagai bentuk rasa dalam menimbulkan semangat guru.

\section{Siklus II}

\section{Perencanaan}

a. Mengumpulkan guru melalui undangan kepala sekolah

b. Menyusun instrumen

c. Menyusun jadwal supervisi klinis mulai dari hari, tanggal, jam serta tempat pertemuan

d. Manyiapkan materi supervisi klinis

e. Menyuruh guru membawa bahan-bahan yang dibutuhkan saat melakukan supervisi klinis

f. Menyiapkan konsumsi untuk supervisi klinis

g. Menyuruh guru membawa laptop dan lainnya

h. Menyiapkan hadiah

\section{Pelaksanaan}

Pelaksanaan kegiatan pada siklus II ini adalah pada hari sabtu, tanggal 7 Agustus 2021 jam 14:00- 17:00 dengan materi mengenai model pembelajaran yang tepat dalam proses belajar mengajar. Kegiatan ini dilaksamakan di SD Negeri 168/X Pandan Sejahtera Kabupaten Tanjung Jabung Timur dengan jumlah guru sebanyak 8 orang. Adapun kegiatan dalam pelaksanaan ini adalah :

a. Peneliti/pengawas menyampaikan konsep serta pelaksaan penelitian.

b. Memulai melakukan supervisi klinis dengan guru-guru yang sudah dikumpulkan.

c. Meminta guru mengutarakan masalah yang dihadapi dalam melaksanakan penilaian perkembanagan anak.

d. Membimbing guru dalam mengatasi masalah yang dihadapi.

e. Melakukan percobaan serta meminta evaluasi guru terhadap perkembangan yang dinilai.

f. Melakukan tanya jawab mengenai masalah yang telah disupervisikan.

\section{Observasi}

Pengamatan (observasi) dilaksanakan bersamaan dengan pelaksaaan supervisi dilakukan. Pada akhir proses pelaksanaan kegiatan dilihat kemampuan guru dalam penggunaaan model 
pembelajaran. Adapun data hasil penelitian pada siklus II adalah sebagai berikut:

Tabel 3. Rekapitulasi Hasil Penelitian Siklus II

\begin{tabular}{|c|c|c|c|}
\hline Rentang Nilai & Jumlah & Persentase (100\%) & Predikat \\
\hline$\geq 90 \%$ & 5 & 62 & Amat Baik \\
\hline $81-90 \%$ & 3 & 38 & Baik \\
\hline $71-80 \%$ & 0 & 0 & Cukup \\
\hline$\leq 70 \%$ & 0 & 0 & Kurang \\
\hline Jumlah & 8 & 100 & \\
\hline
\end{tabular}

Berdasarkan hasil pengamatan yang dilakukan dengan menerapkan supervisi klinis pada siklus II kemampuan guru dalam menggunakan model pembelajaran di SD Negeri 168/X Pandan Sejahtera Kabupaten Tanjung Jabung Timur rata-rata kemampuan guru sudah amat baik. Hal ini dapat dilihat berdasarkan tabel diatas, dari 8 jumlah guru yang ada 5 orang guru (62\%) sudah dikategorikan amat baik, 3 orang (38\%) dengan kategori baik. Oleh sebab itu dari hasil tersebut sudah terjadi peningkatan dari sebelumnya. Untuk lebih jelasnya dapat dilihat pada diagram dibawah ini:

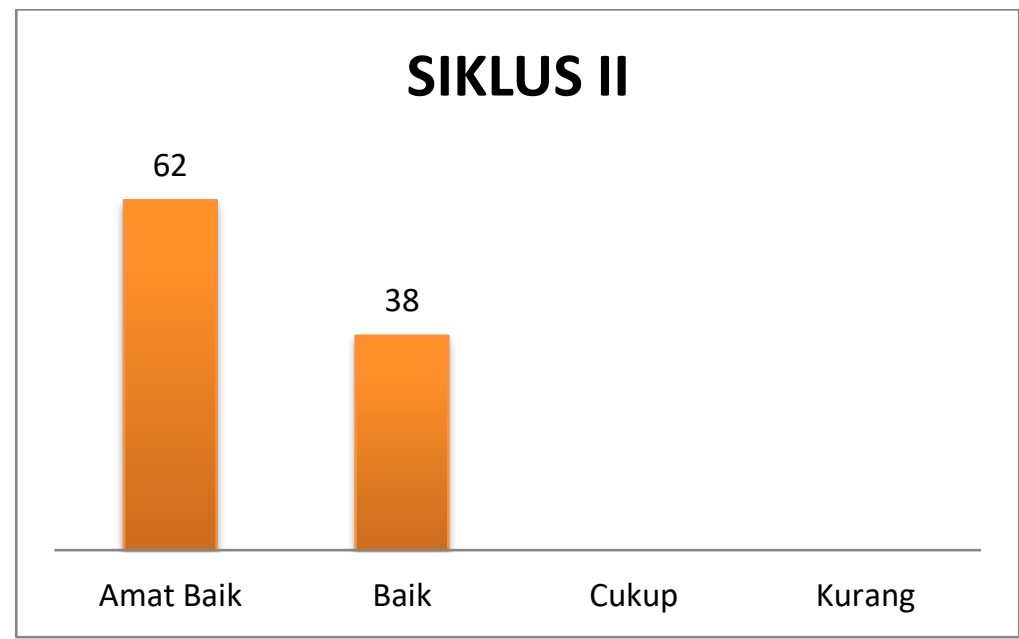

Gambar 3. Hasil Pengamatan Kemampuan Guru Siklus II

\section{Refleksi}

Berdasarkan hasil pengamatan yang dilakukan, maka peneliti bersama dengan kepala sekolah melakukan diskusi diruang majelis guru mengenai proses supervisi yang dilakukan pada siklus II, kepala sekolah yang dijadikan sebagai observer disini memberikan tanggapan atau temuan selama proses pelaksaan supervisi. Adapun temuan yang diamati adalah bahwa temuan-temuan kekurangan yang terjadi pada siklus sebelumnya sudah teratasi, guru sudah paham menggunakan model pembelajaran dan memilih model pembelajaran sehingga melalui supervisi klinis ini mampu meningkatkan kemampuan guru dalam menggunakan model pembelajaran yang baik dan tepat.

\section{Pembahasan}

Melalui hasil penelitian ini menunjukkan bahwa melalui supervisi klinis memiliki dampak positif dalam meningkatkan kemampuan guru dalam menggunakan model pembelajaran. Hal ini dapat 
dilihat dari semakin mantapnya pemahaman guru terhadap materi yang disampaikan peneliti yang ditandai dengan meningkatnya kemampuan guru.

Sebelum menerapkan supervisi klinis, kemampuan guru dalam menggunakan model pembelajaran di SD Negeri 168/X Pandan Sejahtera Kabupaten Tanjung Jabung Timur masih dikatakan rendah. Hal ini dapat dilihat berdasarkan tabel diatas, dari 8 jumlah guru yang ada semuanya masih dikatakan pada kategori gurang dalam menggunakan model pembelajaran. Oleh sebab itu penulis bersama dengan kepala sekolah mengadakan sebuah tindakan atau perubahan dalam merubah kemampuan guru tersebut ke arah yang lebih baik.

Pada siklus I kemampuan guru dalam menggunakan model pembelajaran di SD Negeri 168/X Pandan Sejahtera Kabupaten Tanjung Jabung Timur lengayang rata-rata kemampuan guru masih cukup. Hal ini dapat dilihat berdasarkan tabel diatas, dari 8 jumlah guru yang ada 1 orang guru (12\%) sudah dikategorikan amat baik, 7 orang (88\%) dengan kategori cukup

Hal ini sesuai dengan pengertian kemampuan berasal dari kata mampu yang berarti kuasa (bisa, sanggup) melakukan sesuatu, sedangkan kemampuan berarti kesanggupan, kecakapan, kekuatan (Tim Penyusun Kamus Besar Bahasa Indonesia, 1989: 552-553). Kemampuan (ability) berarti kapasitas seorang individu untuk melakukan beragam tugas dalam suatu pekerjaan. (Stephen P. Robbins \& Timonthy A. Judge, 2009: 57).

Pada siklus II kemampuan guru dalam menggunakan model pembelajaran di SD Negeri 168/X Pandan Sejahtera Kabupaten Tanjung Jabung Timur rata-rata kemampuan guru sudah amat baik. Hal ini dapat dilihat berdasarkan tabel diatas, dari 8 jumlah guru yang ada 5 orang guru (62\%) sudah dikategorikan amat baik, 3 orang (38\%) dengan kategori baik.

Pemahaman umum bahwa peranan utama dari supervisi adalah ditujukan kepada perbaikan pengajaran. Franseth Jane dalam Piet A. Sahertian, berkeyakinan bahwa supervisi akan dapat memberi bantuan terhadap program pendidikan melalui bermacam-macam cara sehingga kwalitas kehidupan akan diperbaiki olehnya. Ayer, Frend E, menganggap fungsi supervisi untuk memelihara program pengajaran yang ada dengan sebaik-baiknya sehingga ada perbaikan. Untuk lebih jelasnya mengenai peningkatan kemampuan guru dapat diihat pada diagram dibawah ini.

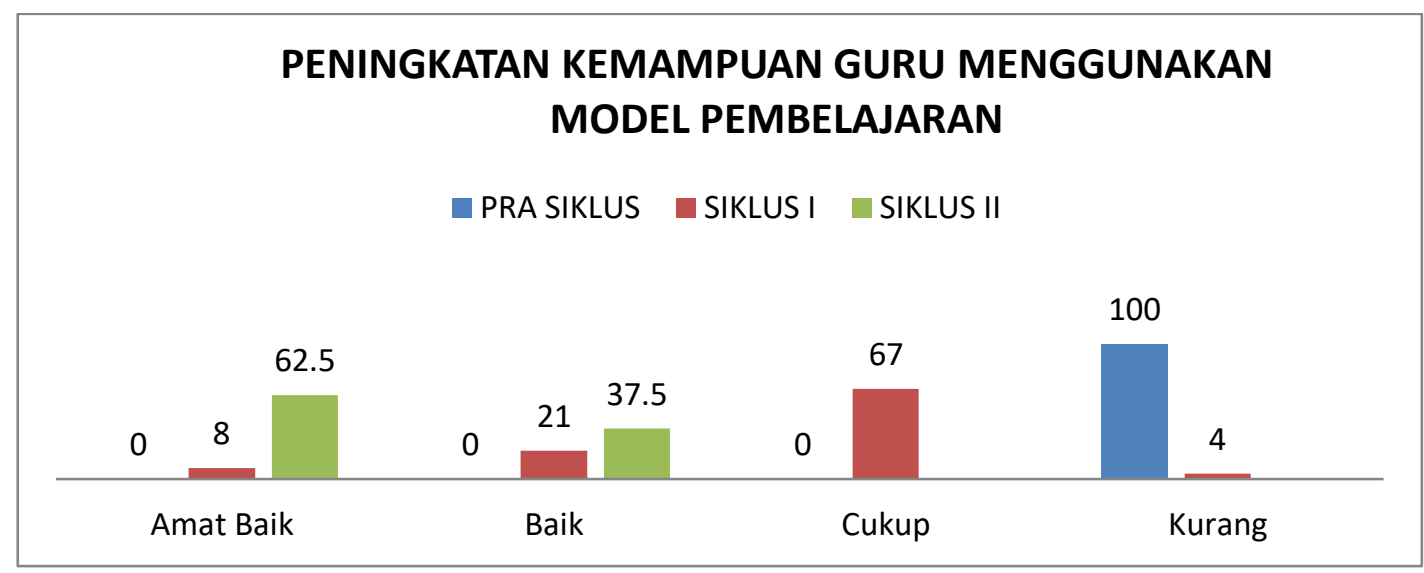

Gambar 4. Peningkatan Kemampuan Guru Menggunakan Model Pembelajaran 


\section{KESIMPULAN}

Berdasarkan hasil penelitian dan pembahasan diatas, maka dapat disimpulkan bahwa dengan menggunakan supervisi klinis dapat meningkatkan kemampuan guru dalam menggunakan model pembelajaran di D Negeri 168/X Pandan Sejahtera Kabupaten Tanjung Jabung Timur dengan tindakan memberikan hadiah. Maka oleh sebab itu supervisi klinis ini sangat cocok digunakan sebagai salah satu cara untuk meningkatkan kemampuan guru tersebut salah satunya dalam menggunakan model pembelajaran.

Berdasarkan penelitian diatas, maka adapun saran untuk penelitian ini adalah :

1. Bagi guru : untuk tetap semangat dan selalu menggali ilmu demi terciptanya susana belajat yang baik

2. Bagi kepala sekolah : untuk dijadikan patokan sebagai salah satu alternatif dalam mengatasi masalah pada guru

3. Bagi dinas : sebagai salah salah satu fasilitator bagi guru dan pembimbing untuk meningkatkan mutu dan kualitas guru kedepannya.

4. Bagi peneliti selanjutnya sebagai bahan referensi dan perbaikan untuk lebih baik lagi.

\section{REFERENSI}

Agus, Suprijono. 2012. Cooperative Learning: Teori dan Aplikasi Paikem. Yogyakrta: Pustaka Pelajar.

Alwi Hasan, dkk. (2005). Kamus Besar Bahasa Indonesia. Jakarta: Departemen Pendidikan Nasional Balai Pustaka.

Arikunto. 2005. Metode Penelitian Kualitatif. Jakarta: Sagung Seto.

Imran.(2010). Pembinaan Guru Di Indonesia. Jakarta: Pustaka Jaya.

Mukhtar dan Iskandar. 2009. Orientasi Baru Supervisi Pendidikan. Jakarta: Gaung Persada.

Purwanto. 2004. Psikologi Pendidikan. Cetakan ke 20. Bandung: Remaja Rosdakarya

Rusman. (2013). Metode-Metode Pembelajaran: Mengembangkan Profesionalisme Guru. Jakarta: PT Raja Grafindo Persada.

Sagala, Syaiful. 2010. Supervisi Pembelajaran dalam Profesi Pendidikan. Bandung: Alfabeta

Stephen P.Robbins, 2009. Manajemen, Jilid 1. Edisi Kesepuluh. Penerbit Erlangga.

Suparlan, 2008, Menjadi Guru Efektif, Jakarta: Hikayat Publishing.

Undang-undang Nomor 20 tahun 2003

Undang-Undang Republik Indonesia Nomor 14 Tahun 2005. 